\title{
PRINSIP-PRINSIP SYARIAH DALAM PENYELESAIAN SENGKETA EKONOMI SYARIAH DI PENGADILAN AGAMA
}

\author{
Norcholis* \\ *Program Studi Ekonomi Syariah Pascasarjana IAIN Madura \\ e-mail: norcholissakun@gmail.com
}

\begin{abstract}
Abstrak: Dalam menyelesaikan sengketa hukum ekonomi syariah harus melalui arbitrase atau pengadilan agama. Dalam penelitian ini akan dibahas mengenai penyelesaian sengketa hukum di Pengadilan Agama. Apakah Pengadilan Agama sudah menerapkan semua prinsip-prinsip syariah dalam menyelesaikan sengketa ekonomi syariah. Prinsip syariah merupakan suatu komitmen dimana sebuah sistem atau tatanan proses harus sesuai dengan ketentuan Agama Islam. Prinsip-prinsip dalam syariat diantaranya adalah tidak mempersulit ('Adam al-Haraj), mengurangi Beban (Taqlil al-Taklif), penetapan hukum secara periodik, sejalan dengan kemaslahatan universal, dan persamaan dan keadilan (al-Musawah wa al-Adalah). Didalam menyelesaikan sengketa ekonomi syariah, harus melihat dulu apakah prosedur penyelesaian sengketa di pengadilan agama sesuai dengan prinsip-prinsip syariah. Biasanya kalau sengketa berbasis syariah prosedurnya harus berdasarkan syariah juga. Pengadilan agama juga harus melaksanakan prosedur sengketa berdasarkan prinsip-prinsip syariah.
\end{abstract}

Kata Kunci: Prinsip-prinsip Syariah, Sengketa Ekonomi Syariah, Pengadilan Agama. 


\section{PENDAHULUAN}

$\mathrm{Di}$

Indonesia

sendiri perkembangan ekonomi syariah cukup mengembirakan. Pasalnya sejak muncul bank syariah pertama yaitu Bank Muamalat Indonesia, maka bermunculan bank-bank lain yang menerapkan prinsip syariah. Bahkan sampai sekarang hampir semua bank konvensional telah membuka unit usaha syariah atau mendirikan bank sendiri yang menggunakan prinsip syariah. Tidak hanya perbankan saja yang berkembang pesat, akan tetapi berbagai lembaga keuangan syariah juga sudah bermunculan. Bahkan beberapa lembaga yang semula tidak menggunakan prinsip syariah sekarang banyak yang berganti nama atau bahkan memberikan label syariah di belakangnya. Munculnya pariwisata syariah, hotel syariah dan lain sebagainya.

Semua lembaga yang menggunakan label syariah tentu dalam pelaksanaan kegiatannya harus menggunakan prinsip-prinsip syariah. Dalam operasionalnya, semua lembaga yang berlabel syariah merupakan bagian dari sistem ekonomi Islam sehingga dituntut untuk tidak saja menghasilkan keuntungan melalui setiap transaksi komersial saja, tetapi juga untuk mengimplementasikan nilainilai syariah yang sesuai dengan ketentuan Al-Qur'an dan Al-Hadits (Rosidah dan Layyin Mahfiana, 2020).

Namun akhir-akhir ini, di dunia perekonomian yang berbasis syariah atau yang lainnya perselisihan antar para pelaku kegiatan tersebut entah itu pemilik atau nasabah yang akan berujung pada sengketa. Sengketa ekonomi syariah merupakan suatu perselisihan atau pertentangan antara dua pihak atau lebih pelaku ekonomi yang kegiatan usahanya dilaksanakan menurut prinsip-prinsip syariah dan asas-asas hukum ekonomi syariah yang disebabkan karena perbedaan pendapat atau perbedaan penafsiran terhadap suatu kepentingan atau hak milik yang dapat menimbulkan sengketa hukum bagi keduanya dan dapat diberikan sanksi hukum kepada keduanya yang bisa menimbulkan kerugian diantara keduanya.

Awal timbulnya sengketa antara para pihak pada dasarnya diawali dengan kerjasama kedua belah pihak, entah itu dalam akad transaksi maupun kerjasama yang lain yang pada akhirnya tidak sesuai dengan apa yang diperjanjikan diawal. Karena ketidaksesuaian itulah salah satu dari masing-masing pihak menggugat kepada lembaga arbitrase atau peradilan.

Di Indonesia sendiri, bila terjadi sengketa diselesaikan melalui berbagai cara. Masing-masing menggunakan pendekatan paradigma yang berbeda sesuai dengan nilai, keinginan, tujuan, budaya yang diyakini pihak yang sedang bersengketa. Pendekatan pertama, yaitu penyelesaian sengketa melalui pengadilan (litigasi) yaitu Pengadilan Agama. Pendekatan ini merupakan suatu pendekatan untuk mendapatkan keadilan melalui sistem perlawanan dan menggunakan paksaan dalam mengelola sengketa serta menghasilkan suatu keputusan menang dan kalah (win-lose solution) bagi pihak-pihak yang bersengketa (Rosidah dan Layyin Mahfiana, 2020).

Sementara itu, pendekatan kedua, paradigma penyelesaian sengketa melalui jalur di luar pengadilan (non litigasi) seperti Basyarnas dan lainnya, Paradigma ini dalam mencapai sebuah keadilan lebih mengutamakan pendekatan perdamaian dan berusaha mempertemukan kedua belah pihak yang bersengketa serta bertujuan untk mendapatkan hasil peneyelesaian sengketa kearah win-win solution, tidak ada pihak yang menang dan yang kalah (Rosidah dan Layyin Mahfiana, 2020). 
Menurut Pasal 1 ayat 1 Undangundang No. 7 Tahun 1989 tentang Peradilan Agama, yang dimaksud dengan Peradilan Agama adalah peradilan bagi orang-orang yang beragama Islam. Menurut Pasal 49 ayat (1) Undangundang No. 7 Tahun 1989 dinyatakan bahwa Pengadilan Agama bertugas dan berwenang memeriksa, memutus, dan menyelesaikan perkara-perkara di tingkat pertama antara orang-orang yang beragama Islam di bidang perkawinan, kewarisan, wasiat dan hibah, serta wakaf dan shadaqah. Namun sejak tahun 2006, setelah diubahnya Undang-undang No.7 Tahun 1989 dengan Undang-Undang No. 3 Tahun 2006, kewenangan Pengadilan Agama menjadi diperluas, yaitu disamping berwenang memeriksa, memutus, dan menyelesaikan sengketa di tingkat pertama antara orang-orang yang beragama Islam di bidang perkawinan, kewarisan, wasiat, hibah, wakaf, zakat, infaq, dan shadaqah, Pengadilan Agama juga berwenang untuk memeriksa, memutus, dan menyelesaikan sengketa di bidang ekonomi syariah.

Selanjutnya,

kewenangan

Peradilan Agama tersebut diperkuat dengan keputusan yang dibuat oleh Mahkamah Konstitusi atas perkara Nomor 93/ PUU-X/2012 yang menghapuskan penjelasan Pasal 55 ayat 2 Undang-undang No. 21 Tahun 2008 tentang Perbankan Syariah, sehingga menjadikan Peradilan Agama satusatunya lembaga Peradilan yang berwenang untuk menyelesaikan sengketa ekonomi syariah. Dalam penjelasan Pasal 49 Undang-undang No.3 Tahun 2006 penyelesaian sengketa ekonomi syariah tidak hanya dibatasi dalam bidang perbankan saja melainkan juga dibidang ekonomi syariah lainya.

Pada tahun 2008 dengan merujuk pada Undang-undang Republik Indonesia No. 30 Tahun 1999, maka penyelesaian sengketa perbankan syariah atau ekonomi syariah dapat ditempuh melalui dua cara yaitu, pengadilan negeri dan badan arbitrase. Namun setelah berlakunya Undang-undang Republik Indonesia No. 21 Tahun 2008 Pasal 55, dengan jelas disebutkan bahwa pengadilan yang berwenang melaksanakan putusan Badan Arbitrase Syariah Nasional (Basyarnas) dan menyelesaikan sengketa perbankan syariah atau ekonomi syariah adalah pengadilan agama (Rosidah dan Layyin Mahfiana, 2020).

Oleh karena itu, berdasarkan pemaparan diatas peneliti ini memfokuskan permasalahannya prinsipprinsip syariah dalam penyelesaian sengketa ekonomi syariah di pengadilan agama.

\section{PEMBAHASAN}

\section{Prinsip-prinsip Syariah}

Dalam menyelesaikan sengketa ekonomi syariah di Pengadilan Agama tentunya harus memperhatikan prinsipprinsip syariah, diantaranya yaitu:

\section{Tidak Mempersulit ('Adam al-Haraj)}

Dalam menetapkan syariat Islam, Al-Qur'an senantiasa memperhitungkan kemampuan manusia dalam melaksanaknnya. Itu diwujudkan dengan memberikan kemudahan dan kelonggaran (tasamuh wa rukhsah) kepada manusia, agar menerima ketetapan hukum dengan kesanggupan yang dimiliknya. Sebagaimana yang diterangkan dalam Surah Al-Baqarah ayat 286 yang berbunyi:

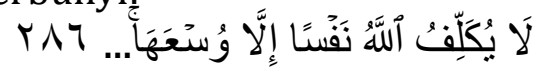

Artinya:"...Allah tidak membebani seseorang melainkan sesuai dengan kesanggupannya...".

Al-Syatibi mengatakan bahwa kesanggupan manusia merupakan syariat hukum mutlak dalam menerima ketetapan hukum syariat. Ketetapan hukum yang tidak terjangkau oleh kemampuan manusia melihat prinsip ini 
tidak sah ditetapkan kepada manusia. Hal ini telah menjadi kesepakatan mayoritas ulama, baik dari kalangan Mu'tazilah (rasionalis) maupun sebagian pengikut Asy'ariah (Sunni tradisionalis).

\section{Mengurangi Beban (Taqlil al-Taklif)}

Prinsip kedua ini merupakan langkah prenventif (penanggulangan) terhadap mukallaf dari pengurangan atau penambahan dalam kewajiban agama. AlQuran tidak memberikan hukum kepada mukallaf agar ia menambahi atau menguranginya, meskipun hal itu mungkin dianggap wajar menurut kacamata sosial. Hal ini guna meringankan dan menjaga nilai-nilai kemaslahatan manusia pada umumnya, agar tercipta suatu pelaksanaan hukum tanpa didasari parasaan terbebani yang berujung pada kesulitan. Hal ini di terangkan dalam Surah Al-Maidah ayat 101 yang berbunyi:

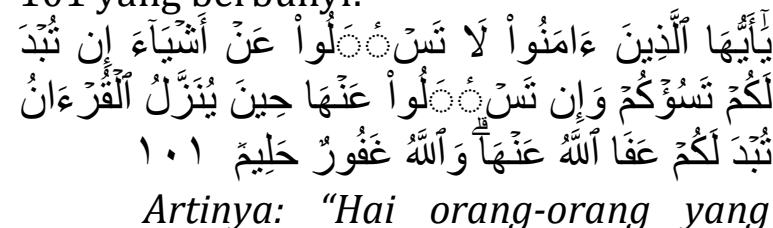
beriman, janganlah kalian menanyakan (kepada Nabimu) hal-hal yang jika diterangkan kepada kalian, niscaya akan menyusahkan kalian dan jika kamu menanyakan diwaktu Al-Quran itu diturunkan, niscaya akan diterangkan kepada kalian, Allah memaafkan (kalian) tentang hal-hal itu. Allah Maha Pengampun lagi Maha Penyayang".

Dengan demikian dapat dipahami bahwa Nabi ketika menerima ayat AlQur'an menafsirkan sesuai kebutuhan masyarakat pada saat itu. Sedangkan yang tidak dibutuhkan didiamkan saja, dengan maksud nantinya ayat-ayat tersebut dapat ditafsiri sesuai dengan kondisi dan situasi yang terjadi di masyarakat pada masa yang akan datang.

\section{Penetapan Hukum secara Periodik}

Al-Qur'an merupakan kitab suci yang dalam prosesi tarsi'(penetapan hukum)' sangat memperhatikan berbagai aspek, baik natural, spiritual, kultural, maupun sosial umat. Dalam menetapkan hukum, Al-Qur'an selalu mempertimbangkan apakah mental spiritual manusia telah siap untuk menerima ketentuan yang akan dibebankan kepadanya. Hal ini terkait erat dengan prinsip kedua, yakni tidak memberatkan umat. Karena itulah, hukum syariat dalam Al-Qur'an tidak diturunkan secara serta merta dengan format yang final, melainkan secara bertahap, dengan maksud agar umat tidak merasa terkejut dengan syariat yang tibatiba. Karenanya, wahyu Al-Qur'an senantiasa turun sesuai dengan kondisi dan realita yang terjadi pada waktu itu.

\section{Sejalan dengan Kemaslahatan Universal}

Manusia adalah objek dan subjek legislasi hukum Al-Qur'an. Seluruh hukum yang terdapat dalam Al-Qur'an diperuntukkan demi kepentingan dan perbaikan kehidupan umat, baik mengenai jiwa, akal, keturunan, agama, maupun pengelolaan harta benda, sehingga penerapan hukumnya Al-Qur'an senantiasa memperhitungkan lima kemaslahatan, disitulah terdapat syariat Islam. Islam bukan hanya doktrin belaka yang identik dengan pembebanan, tetapi juga ajaran yang bertujuan untuk menyejahterakan manusia. Karenanya, segala sesuatu ini merupakan fasilitas yang berguna bagi manusia dalam memenuhi kebutuhannya.

\section{Persamaan dan Keadilan (al-Musawah wa al-Adalah)}

Persamaan hak di muka adalah salah satu prinsip utama syariat Islam, baik yang berkaitan dengan ibadah atau muamalah. Terkait dengan hal ini Allah 
Swt menerangkan dalam Surah An-Nisa' ayat 58 yang berbunyi:

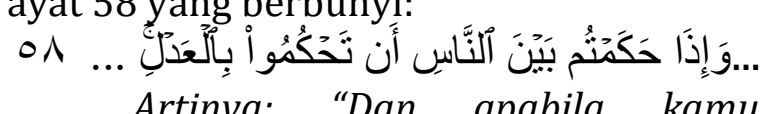

Artinya: "Dan apabila kamu menetapkan hukum di antara manusia, supaya kamu menetapkan dengan adil....".

Ekonomi syariah memiliki perbedaan fundamental dengan sistem ekonomi lainnnya. Perbedaan tersebut terutama sekali menyangkut landasan filosofi dan asumsi-asumsi dasar tentang manusia.

Adiwarman Karim mengemukakan ada empat landasan filosofis sistem ekonomi syariah yang menjadi pembeda utama dengan sistem ekonomi konvensional, yaitu:Pertamatauhid, dalam sistem ekonomi syariah tauhid merupakan landasan fundamental, dengan landasan ketauhidan ini segala sesuatu yang ada merupakan ciptaan Allah Swt dan hanya Allah pula yang mengatur segala sesuatunya terhadap ciptaan-Nya tersebut, termasuk mekanisme hubungan pengaturan rezeki terhadap hamba-hamba-Nya, seperti pemilikannya, cara perolehannya dan pembelanjaannnya (tauhid rububiyyah). Untuk itu para pelaku ekonomi (manusia) harus mentaati segala kaidah yang telah ditetapkan oleh Allah secara kaffah, termasuk dalam bidang aktivitas perekonomian. Ketaatan tersebut bukan hanya dalam kehidupan sosial belaka, tetapi meliputi hal-hal yang bersifat etik dan moral (tauhid uluhiyyah).

Kedua,keadilan dan keseimbangan, sistem ekonomi syariah memandang keadilan dan keseimbangan merupakan sesuatu hal yang mutlak untuk diamalkan olek pelaku ekonomi. Perlunya hal ini berulangkali ditegaskan dalam Al-Qur'an. Keadilan dan keseimbangan merupakan syarat mutlak untuk tercapainya kesejahteraan masyarakat. Keadilan dan keseimbangan harus teraplikasi sedemikian rupa antara anggota masyarakat yang melakukan hubungan ekonomi. Artinya keadilan dan keseimbangan tersebut bukan hanya pada tataran teoritis tetapi juga dalam tataran teknis, misalnya dua orang melakukan hubungan ekonomi.

Ketiga kebebasan, dalam sistem ekonomi syariah, kebebasan merupakan hal pokok. Kebebasan dimaksudkan bahwa manusia bebas untuk melakukan aktivitas ekonomi sepanjang tidak ada larangan dari Allah Swt. Pelaku ekonomi dalam sistem ekonomi syariah diberikan keleluasaan untuk berkreatifitas dan berinovasi dalam mengembangkan kegiatan ekonomi.

Keempat pertanggungjawaban, dalam sistem ekonomi syariah manusia sebagai khalifah pemegang amanah Allah di muka bumi. Dalam melakukan aktivitas (termasuk aktivitas ekonomi) diberikan keleluasaan untuk memilih apa yang terbaik untuk dirinya. Sebagai hamba Allah akan dimintakan pertanggungjawaban atas segala yang telah dilakukan. Dengan empat landasan filosofis, menjadikan sistem ekonomi syariah memiliki keistimewaan dibanding sistem ekonomi konvensional. Sistem ekonomi syariah tidak memandang manusia sebagai makhluk ekonomi yang mendewakan materi, akan tetapi memandang manusia memiliki fitrah sebagai makhluk yang memiliki kasih sayang. Dengan adanya rasa kasih sayang akan melahirkan perbuatan tolong menolong antar sesama (tâ̂wun dan takaful). (Sufiarina, 2017).

Prinsip-prinsip bermuamalah dalam Islam menurut Metwally yaitu: Pertama, sumber daya alam adalah milik Allah, sehingga pemanfaatannya oleh manusia harus memperhatikan tanggung jawab di akhirat. Sehingga dalam pemanfaatannya manusia harus memperhatikan pemanfaatan tidak hanya untuk diri sendiri tetapi juga harus memperhatikan kepentingan orang lain. 
Kedua, hak milik pribadi diakui secara terbatas, ada aspek kepentingan masyarakat yang harus diperhatikan sehingga untuk memperoleh hak pribadi harus mempergunakan cara-cara yang halal atau sah. Ketiga, Islam mengajarkan manusia bekerja dan berjuang untuk mendapatkan harta yang halal dengan cara dan aturan yang telah ditentukan di dalam kitab suci, karena pada dasarnya setiap makhluk telah dijamin rezekinya oleh Allah. Keempat, hak kepemilikan kekayaan tidak boleh hanya dikuasai oleh sebagian kecil orang, karena dapat menghambat produktifitas nasional dan memperlambat terciptanya kesejahteraan masyarakat. Kelima, sumber-sumber produksi yang penting bagi negara dan yang menguasai hajat hidup orang banyak dijamin penggunaannya untuk kepentingan umum/ orang banyak. Keenam, Setiap tindakan manusia selalu ada pertanggungjawabannya dihadapan AllahSwt, sehingga mendorong umat Islam untuk menghindarkan diri dari cara-cara yang mengandung unsur riba, maisir, gharar dan upaya yang melampaui batas. Ketujuh, membayar zakat bagi yang telah mencapai nisab adalah bentuk pendistribusian yang adil bagi orang kaya terhadap orang miskin. Kedelapan, riba dalam bentuk apapun dilarang dalam Islam.

\section{Sengketa Ekonomi Syariah}

Sengketa adalah pertentangan, perselisihan, atau percekcokan yang terjadi antara pihak yang satu dengan pihak lainnya yang berkaitan dengan hak yang bernilai, baik berupa uang atau benda. Sengketa atau konflik merupakan setiap situasi pertentangan kepentingan antara dua orang atau lebih dimana dua atau lebih pihak yang memperjuangkan tujuan-tujuan tertentu dari masing-masing pihak, saling memberikan tekanan dan satu sama lain tetapi gagal mencapai satu pendapat dan masing-masing pihak saling berusaha untuk memperjuangkan secara sadar tujuan-tujuan pokok mereka yang kehendaki (Rosidah dan Layyin Mahfiana, 2020).

Pada umumnya, sengketa yang mucul dikarenakan ada wanprestasi atau ingkar janji oleh pihak-pihak atau salah satu pihak tidak melakukan apa yang diperjanjikan atau disepakati untuk dilakukan, atau pihak yang satu melaksanakan apa yang disepakati tetapi tidak tunai, atau pihak yang satu melaksanakan apa yang diperjanjikan tetapi keliru dan atau salah satu pihak melaksanakan prestasi atau apa yang diperjanjikan tetapi tidak tepat waktu, sehingga apa yang dilakukan oleh salah satu pihak inilah yang memicu timbulnya sengketa.

Diantara faktor penyebab yang lazim terjadi dalam sengketa ekonomi syariah adalah:

a. Akad yang dibuat oleh para pihak yang tidak transparan atau hanya ditentukan oleh salah satu pihak saja terutama pihak yang berada pada posisi yang kuat, sehingga pihak yang lain tidak memahami isi akad dengan baik.

b. Isi akad yang tidak mudah untuk dilaksanakan karena salah satu pihak yang kurang hati-hati dalam melakukan perundingan, salah satu pihak tidak mempunyai keahlian di dalam negosiasi kesepakatan isi akad, salah satu pihak tidak mempunyai keahlian di dalam mencermati risiko yang mungkin akan terjadi dari akad tersebut.atau salah satu pihak tidak jujur dalam melaksanakan akad.

Dari segi akad atau perjajian yang dibuat oleh para pihak, ada beberapa bentuk akad yang berpotensi sengketa di kemudian hari, diantaranya adalah:

a. Salah satu pihak menemukan fakta bahwa syarat-syaratnya suatu 
akad, baik syarat subjektif maupun objektif yang ternyata tidak terpenuhi sehingga menuntut pembatalan akad;

b. Akad diputus oleh satu pihak tanpa persetujuan pihak lain dan perbedaan menafsiran isi akad oleh para pihak sehingga menimbulkan sengketa hukum;

c. Karena salah satu pihak tidak memenuhi prestasi sebagaimana yang telah diperjanjikan;

d. Terjadinya perbuatan melawan hukum

e. Adanya risiko yang tidak terduga pada saat pembuatan akad.

\section{Pengadilan \\ Kewenengannya} Agama

dan

Sepanjang ada umat Islam, sepanjang itu pula Peradilan Agama ada, meskipun pada awalnya masih dalam bentuk dan corak yang sederhana dan nama yang berbeda-beda. Karena itu, dalam dinamika perjalanan sejarah Indonesia, keberadaan Peradilan Agama bukan sesuatu yang baru. Bahkan jauh sebelum Indonesia merdeka, yaitu sejak masa kerajaan-kerajaan Islam nusantara, Peradilan Agama telah menjalankan fungsinya yang tidak hanya terbatas pada perkara-perkara keperdataan, tetapi juga perkara pidana (Aripin, 2012).

Menurut Pasal 1 ayat (1) Undangundang No. 7 Tahun 1989 tentang Peradilan Agama, yang dimaksud dengan Peradilan Agama adalah peradilan bagi orang-orang yang beragama Islam. Kemudian, menurut Pasal 49 ayat (1) Undang-undang No. 7 Tahun 1989 dinyatakan bahwa Pengadilan Agama bertugas dan berwenang memeriksa, memutus, dan menyelesaikan perkaraperkara di tingkat pertama antara orangorang yang beragama Islam di bidang perkawinan, kewarisan, wasiat dan hibah, serta wakaf dan shadaqah yang dilakukan berdasarkan hukum Islam.
Namun sejak tahun 2006, setelah diubahnya Undang-undang No. 7 Tahun 1989 dengan Undang-undang No. 3 Tahun 2006, kewenangan Pengadilan Agama menjadi diperluas yaitu Pengadilan Agama juga berwenang untuk memeriksa, memutus, dan menyelesaikan sengketa di bidang ekonomi syariah. Selanjutnya, kewenangan Peradilan Agama tersebut diperkuat dengan putusan Mahkamah Konstitusi atas perkara Nomor 93/ PUU$\mathrm{X} / 2012$ yang menghapuskan penjelasan Pasal 55 ayat 2 Undang-undang No. 21 Tahun 2008 tentang Perbankan Syariah, sehingga menjadikan Peradilan Agama satu-satunya lembaga Peradilan yang berwenang untuk menyelesaikan sengketa ekonomi syariah. Dalam penjelasan Pasal 49 Undang-undangU No.3 Tahun 2006 penyelesaian sengketa ekonomi syariah tidak hannya dibatasi dalam bidang perbankan saja melainkan juga dibidang ekonomi syariah lainya.

Pada dasarnya putusan arbitrase yang bersifat final dan mengikat, dilaksanakan oleh para pihak dengan secara suka rela, dalam hal putusan tidak dilaksanakan secara suka rela, tetapi pelaksanaan putusan tersebut harus dipaksakan sebagaimana putusan Arbitrase pada umumnya maka putusan arbitrase syariah juga dilaksanakan oleh Pengadilan Agama hal ini berdasarkan surat Edaran Mahkamah Agung No 8 tahun 2008 Ketua Pengadilan Agama mengeluarkan perintah eksekusi atas permohonan salah satu pihak yang bersengketa.

Putusan Badan Arbitrase Syariah tidak bisa dilaksanakan begitu saja. SEMA No. 8 Tahun 2008 mengajukan beberapa syarat. Pertama, dalam waktu paling lama 30 (tiga puluh) hari terhitung sejak tanggal putusan Badan Arbitrase diucapkan, lembar asli atau salinan otentik putusan diserahkan dan didaftarkan oleh arbiter atau kuasanya ke Panitera Pengadilan Agama. Kedua, 
penyerahan dan pendaftaran dilakukan dengan mencatat dan menandatangani pada bagian pinggir atau akhir putusan. Ketiga, Arbiter atau kuasanya wajib menyerahkan putusan dan lembar asli pengangkatan sebagai arbiter kepada Panitera Pengadilan Agama.

Setelah menerima permohonan eksekusi dari salah satu pihak, Ketua Pengadilan Agama wajib memeriksa terlebih dahulu tiga hal. Setelah memeriksa ketiga hal inilah baru Ketua Pengadilan Agama menerbitkan perintah pelaksanaan eksekusi putusan. Pertama, memeriksa apakah persetujuan untuk menyelesaikan sengketa melalui Badan Arbitrase Syariah dimuat dalam suatu dokumen yang ditandatangani oleh para pihak. Kedua, memastikan apakah sengketa tersebut adalah sengketa di bidang ekonomi syariah dan mengenai hak yang menurut hukum dan peraturan perundang-undangan

dikuasai sepenuhnya pihak yang bersengketa. Ketiga, memeriksa apakah putusan Badan Arbitrase tidak bertentangan dengan prinsip-prinsip syariah. Dengan demikian, Ketua Pengadilan Agama tidak memeriksa alasan atau pertimbangan dari putusan Badan Arbitrase.

Dalam menyelesaikan sengketa ekonomi syariah, pengadilan agama tentunya harus melakukan beberapa tahap proses, dimana proses itu dimulai dari tuntutan dari seseorang atau lembaga kepada seseorang atau lembaga hingga mencapai suatu kesepakan antara kedua belah pihak. Dimana dalam proses tersebut jika sengketa tersebut merupakan sengketa ekonomi syariah tentunya harus menggunakan prinsipprinsip syariah.

\section{SIMPULAN}

Prinsip-prinsip dalam syariat diantaranya adalah tidak mempersulit ('Adam al-Haraj), mengurangi Beban (Taqlil al-Taklif), penetapan hukum secara periodik, sejalan dengan kemaslahatan universal, dan persamaan dan keadilan (al-Musawah wa al-Adalah). Sengketa merupakan pertentangan, perselisihan, atau percekcokan yang terjadi antara pihak yang satu dengan pihak lainnya yang berkaitan dengan hak yang bernilai, baik berupa uang atau benda. Sengketa atau konflik ini, biasanya terjadi antara dua orang atau lebih yang memperjuangkan hak-haknya masing-masing. Didalam menyelesaikan sengketa ekonomi syariah, harus melihat dulu apakah prosedur penyelesaian sengketa di pengadilan agama sesuai dengan prinsip-prinsip syariah. Biasanya kalau sengketa berbasis syariah prosedurnya harus berdasarkan syariah juga. Pengadilan agama juga harus melaksanakan prosedur sengketa berdasarkan prinsip-prinsip syariah.

\section{DAFTAR RUJUKAN}

Aripin,H. Zaenal. (2012). 130 Tahun Peradilan Agama dari Serambi Mesjid ke Serambi Dunia, Dirjen Badilag Mahkamah Agung R.I. Jakarta.

Rosidah, N., \& Zaidah, L. M. (2020). Efektifitas Penerapan Prinsip Syariah dalam Penyelesaian Sengketa Ekonomi Syariah di Badan Arbitrase Syariah Nasional (BASYARNAS). TAWAZUN: Journal of Sharia Economic Law, 3(1), 16.

Sufiarina, S. (2017). Urgensi Pengadilan Agama Sebagai Penyelesai Sengketa Ekonomi Syariah. Jurnal Hukum \& Pembangunan, 43(2), 204-222. 